\title{
Global climate adaptation governance in the Amazon through a polycentricity lens
}

DOI: http://dx.doi.org/10.1590/0034-7329201900207

Rev. Bras. Polít. Int., 62(2): e007, 2019

Revista Brasileira de Política Internacional ISSN 1983-3121

http://www.scielo.br/rbpi

${ }^{1}$ Fronika Claziena Agatha de Wit

${ }^{1}$ Universidade de Lisboa, Instituto de Ciências Sociais - Gl Ambiente, Território e Sociedade Lisboa, Lisboa, Portugal (fronikadewit@gmail.com)

iD ORCID ID: orcid.org/0000-0002-6181-3537

\section{${ }^{2}$ Paula Martins de Freitas}

${ }^{2}$ Faculdade da Amazônia Ocidental, Biology, Rio Branco, Acre, Brazil (paulitamfreitas@gmail.com)

iD ORCID ID: orcid.org/0000-0003-2415-1842

\section{Copyright:}

- This is an open-access article distributed under the terms of a Creative Commons Attribution License, which permits unrestricted use, distribution, and reproduction in any medium, provided that the original author and source are credited.

- Este é um artigo publicado em acesso aberto e distribuído sob os termos da Licença de Atribuição Creative Commons, que permite uso irrestrito, distribuição e reprodução em qualquer meio, desde que o autor e a fonte originais sejam creditados.
Received: April 30, 2019

Accepted: August 15, 2019

\section{Introduction}

\section{Abstract}

The 2015 Paris agreement has made adaptation to climate change a global goal and increased the polycentricity of the governance landscape. This study uses insights from polycentric governance theory to analyze the emergence of adaptation governance (AG) in Brazil and its implications for the state of Acre, situated in the Amazon region. By using a qualitative data analysis, including subnational climate policies and semi-structured interviews, we aim to analyze the advantages and challenges of polycentric AG in Acre and provide recommendations for improved AG in the region.

Keywords: polycentric theory; Brazilian Amazon; adaptation governance.

C limate change is one of the scientifically defined planetary boundaries to establish a safe operating space on earth, and global climate governance is fundamental to stop development from trespassing these boundaries (Steffen et al. 2011). For over two decades, global climate governance has been institutionally framed by the United Nations Framework Convention on Climate Change (UNFCCC) (Stripple and Bulkeley 2011). Since 2015, with the signing of the UN Paris Agreement, the climate governance landscape has been rapidly changing (Jordan et al. 2018). We highlight two major changes. First, a shift from a single focus on climate change mitigation, to a mitigation and adaptation combo, as the latter is recognized for the first time as a global goal (Hall and Persson 2018). Second, post-Paris climate governance has become more polycentric and multi-actor (Jordan et al. 2018), innovating on its predecessor, the Kyoto Protocol's conception of power and governance, by emphasizing 
the responsibility of multiple (non-)state actors across different scales, to collaborate in their climate mitigation and adaptation measures (Jordan et al. 2015).

Global Adaptation Governance (AG) is an often overlooked concept in political science research despite its implications on "most areas of world politics" (Biermann and Boas 2010, 223). Equally absent from climate governance research in general, and AG in particular, is the study of the impact and effectiveness of the emerging patterns of polycentric governance landscape (Jordan et al. 2015). Climate adaptation is not just a problem of the cities that needs to be solved at the local level. To ensure effective solutions, a response must be harmonized across different levels and scales of governance (Vogel and Henstra 2015). Research on new forms of climate governance and polycentricity in the developed world is rapidly increasing (Bulkeley and Betsill 2016). Notwithstanding, a research gap persists on global climate governance and polycentricity in the Global South, especially in relation to adaptation (Araos et al. 2016).

This article looks at the emerging global adaptation regime (Hall and Persson 2018) and zooms into the Brazilian Amazon, because of its importance for the global climate regime. It is a so-called tipping element: a large-scale component of the Earth system that may pass a tipping point (Lenton et al. 2008). A combination of global climate change and local land use change might turn the Amazonian forest from a carbon sink into a carbon emitter (Nepstad et al. 2008). However, Amazonian deforestation is not only contributing to global climate change, but also threatening local climate stability and thereby increasing the vulnerability of its socio-ecological system (Marengo et al. 2018). The Intergovernmental Panel on Climate Change (IPCC) warns for a possible reduction in projected food availability in the Amazon when global warming exceeds $1.5^{\circ} \mathrm{C}$ (Intergovernmental Panel on Climate Change 2018).

In this light, this article analyzes the potentials and pitfalls of polycentric AG for the Brazilian Amazon. As the Brazilian Amazon comprises nine States, all with their own AG, we chose to use the State of Acre, considered a pioneer in subnational climate governance (Stickler 2014) and innovative transnational collaborations (Perz 2016), as our case study. To collect and triangulate data on AG in Acre, we used two qualitative research methods. First, we analyzed subnational policy documents regarding climate governance, in order to gain insight into the perspectives on and framing of adaptation to climate change. Second, we conducted 18 semi-structured interviews with stakeholders in Acre's climate governance, including subnational government, local and international NGOs, indigenous organizations and university representatives. The transcribed interviews were coded and qualitatively analyzed, using MaxQDA software for qualitative data analysis.

Taking stock of polycentric governance theory, this article aims: 1) to review the emergence of AG in Brazil between 2008 and 2018; and 2) to examine specific AG options for the State of Acre in the Brazilian Amazon. This article's structure is four-fold. First, we provide an overview of the state of the art of global AG and present our theoretical framework of polycentric theory applied to climate adaptation. Second, we review the emergence of global and Brazilian AG. Third, we analyze the advantages and challenges of subnational AG in the Amazon, using the State of Acre as our case study. Finally, the fourth and last section advances a set of policy recommendations for Acre's AG. 


\section{Global adaptation governance through a polycentricity lens}

Almost four decades ago, Rosenau (1992) introduced the term global governance, emphasizing the changing role of governance in a globalizing world and the inclusion of non-governmental mechanisms without formal authority. An example is the field of global climate governance, in which International Relations (IR) scholars have shown an increasing interest.

Most IR scholars focus on mitigation and the causes of climate change, as adaptation is seen as a local level response to the consequences of climate change (Adger et al. 2005). Also, operationalizing climate adaptation is more complex than mitigation: where mitigation can be expressed in lowered carbon emissions, the concept of adaptation lacks a clear operationalization of how to measure the process and what 'the act of adapting' consists of (G. R. Biesbroek et al. 2014). The IPCC, in its fifth assessment report (AR5), defines adaptation as: "the process of adjustment to actual or expected climate and its effects" (Intergovernmental Panel on Climate Change 2014). They distinguish between adaptation in human and natural systems: for the first, "adaptation seeks to moderate or avoid harm or exploit beneficial opportunities," and in the second "human intervention may facilitate adjustment to expected climate and its effects" (Intergovernmental Panel on Climate Change 2014, 5). In AR5 they also provide principles for effective adaptation, stating, among other things, with high confidence that "adaptation is place- and context-specific" and "can be enhanced through complementary actions across levels." In relation to the difference between mitigation and adaptation, AR5 points to "significant co-benefits, synergies, and trade-offs" between the two (Intergovernmental Panel on Climate Change 2014, 6).

The evolution of the global climate regime and the incorporation of adaptation as a global goal relates to a struggle of framings in regard to the climate challenge between the developed and developing countries (Hulme 2017). Where developed countries frame climate change merely as a technical problem that needs collaboration towards low-carbon technologies, developing countries frame it as a developmental problem and stress the need for global socio-technical solutions. Based on equity and justice concerns, the developing countries succeeded in pairing the need for socio-economic development and adaptation alongside emission reduction technology agreements (Okereke 2010). To this effect, Article 7.2 of the Paris Agreement made "enhancing adaptive capacity, strengthening resilience and reducing vulnerability to climate change" a global goal (United Nations Framework Convention on Climate Change 2015) and challenged the framing of adaptation as an exclusive local concern. Magnan and Ribera (2016) understand adaptation as a Global Public Good (GPG), as climate change could lead to the displacement of peoples or new global public health challenges, challenges that can only be addressed through international cooperation. The different framings of adaptation, however, make this a highly contested GPG (Hall and Persson 2018). 


\section{Polycentricity theory and adaptation governance}

Polycentric governance was initially defined as "many centers of decision-making which are formally independent of each other [...] to the extent that they take each other into account in competitive relationships, enter into various contractual and cooperative undertakings or have recourse to central mechanisms to resolve conflicts" (Ostrom et al. 1961, 831). Elinor Ostrom linked polycentric governance to climate governance, highlighting its importance to "[...] enhance innovation, learning, adaptation, trustworthiness, levels of cooperation of participants and the achievement of more effective, equitable, and sustainable outcomes at multiple scales [...]" (Ostrom 2010, 552).

Recently, Jordan et al. (2018) critically studied the strengths and weaknesses of polycentric climate governance and presented its five core propositions: 1) Local action: governance initiatives are likely to take off at a local level through processes of self-organization; 2) Mutual adjustment: governing units spontaneously collaborate; 3) Experimentation: experimentation facilitates innovation and learning; 4) Trust: trust builds up quicker when units self-organize; 5) Overarching rules: local initiatives work best when there are overarching rules.

Applying these propositions to the emerging polycentric AG landscape (see also Table 1), Biesbroek and Lesnikowski (2018) distinguish between three stands of AG literature: adaptive governance, multilevel governance and network governance. Each strand relates to polycentric theory in a different way. The first strand on adaptive governance makes a strong normative claim for polycentric governance principles. In a study on water governance, Pahl-Wostl and Knieper (2014) highlight that polycentricity has the highest explanatory power for high adaptation performance and argue it may be an important pathway towards building adaptive capacity.

Table 1. Polycentric Adaptation Governance

\begin{tabular}{|c|c|c|}
\hline $\begin{array}{l}\text { Core Proposition } \\
\text { Polycentric Theory }\end{array}$ & Explanation & Application to Adaptation Governance \\
\hline 1. Local Action & $\begin{array}{l}\text { Governance initiatives are likely } \\
\text { to take off at a local level through } \\
\text { processes of self-organization }\end{array}$ & $\begin{array}{l}\text { Most adaptation initiatives are local, but there are } \\
\text { trade-offs between different contexts and higher } \\
\text { (inter)national level coordination is needed. }\end{array}$ \\
\hline 2. Mutual Adjustment & $\begin{array}{l}\text { Governing units spontaneously } \\
\text { collaborate }\end{array}$ & $\begin{array}{l}\text { Mutual adjustments are a key part of the debates on } \\
\text { adaptation, providing room for governing units to } \\
\text { connect, collaborate and create trusting relations. }\end{array}$ \\
\hline 3. Experimentation & $\begin{array}{l}\text { Experimentation facilitates, } \\
\text { innovation and learning }\end{array}$ & $\begin{array}{l}\text { Many examples of urban adaptation experiments, } \\
\text { but mostly biased towards leading (Western } \\
\text { democratic) cities and local contexts. }\end{array}$ \\
\hline 4. Trust & $\begin{array}{l}\text { Trust builds up quicker when } \\
\text { units self-organize }\end{array}$ & $\begin{array}{l}\text { Understudied element. Mainly related to increasing } \\
\text { social capital. }\end{array}$ \\
\hline 5. Overarching Rules & $\begin{array}{l}\text { Local initiatives work best when } \\
\text { there are overarching rules }\end{array}$ & $\begin{array}{l}\text { Necessity of overarching rules for adaptation } \\
\text { governance to ensure that adaptation takes place in } \\
\text { a coherent and consistent manner. }\end{array}$ \\
\hline
\end{tabular}

Source: Adapted from Biesbroek and Lesnikowski (2018) 
The literature on multilevel governance is related to the first two propositions of polycentric theory: it focuses on localism and possible conflicts stemming from connections across levels. However, Biesbroek and Lesnikowski warn for the problematic statement that 'adaptation is local,' "[...] as it suggests that there are no trade-offs between different contexts and that higher (inter)national-level coordination is not necessary for climate action" (Biesbroek and Lesnikowski 2018, 312). An example of multilevel AG is the study by Rayner and Jordan (2013) that looks at polycentricity and European Union (EU) adaptation policy. The authors ask for greater attention to how the EU seeks to manage governance challenges both within and across the adaptation and mitigation domains.

The third strand of literature on network governance highlights the relationship between public and private actors and the implications of different network configurations. This body of literature is linked to the third proposition of polycentric theory: experimentation. Urban adaptation experimentation and innovation are very present in the AG literature, but with a bias towards Western cities (Bulkeley et al. 2013). This bias also exists in relation to the fifth proposition: the necessity for overarching rules to ensure coherent and consistent AG (Amundsen et al. 2010). These rules are often not in place in cities and regions in the Global South, leading to highly uneven adaptation progresses across places, jurisdictions and vulnerable groups (Lesnikowski et al. 2016).

\section{The emergence of Brazilian adaptation governance}

Between 2008 and 2011, Brazil showed high climate commitment, including: the release of the National Climate Plan (PNMC) in 2008; a voluntary commitment submitted to the UNFCCC in 2009; the passing of the Climate Law in Congress in December 2009; and the specific modification of the climate law in December 2010 (Viola and Franchini 2018). Although the PNMC claims to define actions and measures aimed at mitigation and adaptation to climate change, the core of the plan is deforestation reduction. Out of its seven objectives, only objective 6 is directly linked to climate adaptation. The 2009 Climate Law also mentions the necessity to address the topic of adaptation: article 4.5 highlights the need to "implement means to promote climate adaptation," and article 5 points to the elaboration of: "means of adaptation to reduce the adverse effects of climate change and the vulnerability of environmental, social and economic systems" (subsection iii); and "the elaboration of integrated climate mitigation and adaptation strategies on the local, regional and national level (subsection iv)." However, also in this case, its core objective is to constrain carbon emissions.

After this active period, Brazil noticeably lowered its dedication to climate change and prioritized economic growth (Viola and Franchini 2018). The only development was the 
elaboration of four new sectoral plans ${ }^{1}$ in 2012 and the revision of four already existing plans ${ }^{2}$. Although all sectoral plans mention both mitigation and adaptation actions and measures, their focus is on mitigating carbon emissions. During the revision and elaboration of these eight sectoral plans, Brazil discovered a gap in its PNMC: a coherent and integrated national plan for climate adaptation (Ministério do Meio Ambiente 2013). In 2012, it therefore created an Adaptation Working Group (WG), with the elaboration of a national plan on climate adaptation as its main goal. In May 2016, Brazil presented its National Adaptation Plan (NAP) in two volumes: the first contains the plan's structural components; the second discusses Brazil's main vulnerabilities regarding climate change, and proposes guidelines to increase climate resilience of 11 thematic sectors ${ }^{3}$. The plan's objective is to promote reduction and management of climate risks in Brazil, and to build instruments that enable adaptation of natural, human, productive and infrastructure systems (Brazil 2016). NAP highlights the importance of multi-level governance: "Measures for adaptation need also to be aligned with national socioeconomic development goals, and with coordinated federal, state and municipal public policies for reduction of inequalities" (Brazil 2016, 38). It also emphasizes the importance of multi-actor governance and enhancing "interaction among public authorities, sectoral bodies of the Brazilian economy, academics, civil society and other stakeholders, as a means of fostering continuous development of national adaptation strategies" (Brazil 2016, 38).

\section{Domestic adaptation governance and the Amazon}

According to Viola and Franchini (2018), there are three types of behavior regarding the Amazon that have negatively affected climate commitment: Amazon Paranoia, Amazon Impotence and Amazon Neglect. Amazon Paranoia describes behavior based on the notion that the region and its resources are desired by the Global North. Amazon Impotence reveals the notion that deforestation is unstoppable. Finally, Amazon Neglect justifies behavior based on the notion that even when deforestation is possible, it is not a policy priority. Although Brazil was able to overcome the first two types of behavior, Amazon Neglect has been rapidly increasing since 2011.

Amazon Neglect is also the case for Brazil's domestic AG: the NAP contains few references to the Amazon. Although it describes how the region will be impacted by higher temperatures and reduced precipitation, and highlights the probability of extreme events, such as droughts and floods

\footnotetext{
1 The four new sectoral plans for climate mitigation and adaptation are: a sectoral plan on transportation and urban mobility; a sectoral plan on the manufacturing sector; a sectoral plan on low-carbon mining; and a sectoral mitigation and adaptation plan for the health sector.

2 The four revised sectoral plans for climate mitigation and adaptation are: an action plan to prevent and control Amazon deforestation; an action plan to prevent and control Savanna deforestation; a plan for low-carbon agriculture; and a sectoral plan on energy.

3 The eleven thematic sectors of Brazil's National Adaptation Plan are: Agriculture, Biodiversity and Ecosystems, Cities, Disasters, Industry and Mining, Infrastructure (Electric Power, Transport and Urban Mobility), Vulnerable Populations, Water Resources, Health, Food and Nutritional Security, and Coastal Zones (Brazil 2016).
} 
(Brazil 2016), it does not provide place-based adaptation measures. NAP's Vulnerable Populations (VP) strategy highlights that the highest percentage of VPs is concentrated in the Amazon Biome $(60,3 \%)$ and that "most are part of groups related to the environment" (Brazil 2016, 186). These VPs might face severe impacts of climate change, such as: reduction of fish stocks, loss of crops, loss of means of survival and an increase of diseases due to rising temperatures and forest fires (Brazil 2016). NAP mentions the importance of mapping the different vulnerable groups and their exposure, sensitivity and adaptive capacity to climate change. It refers to the online digital platform SOMAI (System of Observation and Monitoring of the Indigenous Amazon) developed by the Amazon Environmental Research Institute (IPAM): an auxiliary tool for the planning of adaptation actions that provides access to information on climate scenarios and vulnerabilities for Amazonian indigenous territories.

The only other strategy mentioning the Amazon is the Water Resources Strategy. This strategy discusses the importance of increasing the effectiveness of river basin governance and the need to "consider more appropriate management models for the Amazon region" (Brazil 2016, 271).

\section{Foreign adaptation policy}

Only since the early 2000s has climate adaptation become part of international climate politics (Hall and Persson 2018). In 2010, during COP 16 in Cancun, parties signed the Cancun Adaptation Framework (CAF) and established the Adaptation Committee to promote the implementation of enhanced action on adaptation in a coherent manner (United Nations Framework Convention on Climate Change 2010). Five years later, the Paris agreement framed adaptation as a global challenge, with local, subnational, national, regional and international dimensions (United Nations Framework Convention on Climate Change 2015). In its lead-up, Parties were invited to submit 'Undertakings in adaptation' and include planned adaptation measures in their Intended Nationally Determined Contributions (INDCs).

Brazil's INDC includes mitigation, adaptation and means of implementation. In relation to mitigation, the INDC has a clear objective, and "intends to commit to reduce greenhouse gas emissions by $37 \%$ below 2005 levels in 2025" (Brazil 2015). However, regarding adaptation, Brazil refers to the elaboration-in-progress of its NAP and presents the following objectives: 1) to implement knowledge management systems; 2) to promote research and technology development for adaptation; and 3) to develop processes and tools in support of adaptation actions and strategies, at different levels of government" (Brazil 2015). Although the INDC highlights the importance of multi-level governance for adaptation and enhancing coherence of national and local development strategies with adaptation measures, it does not provide examples of such actions. In regard to the Amazon, Brazil's INDC only mentions the objective of strengthening policies and measures to achieve zero illegal deforestation by 2030 (Brazil 2015). 


\section{Potentials and pitfalls for subnational adaptation governance in the Amazon}

Both Brazil's NAP and INDC stress the need for multi-level government and the involvement of the subnational level. The Brazilian Amazon, made up of nine states ${ }^{4}$, is a heterogeneous region with diverse regional strategies (Becker 2005). We focus on AG in Acre: a pioneer in subnational climate governance (Stickler 2014) and innovative transnational collaborations (Perz 2016).

To gain insight on the status of AG in Acre, we used a two-fold qualitative research methodology: policy analysis and semi-structured interviews. First, we analyzed the four following subnational climate adaptation-related policy documents: 1) Acre's System of Incentives for Environmental Services (2010); 2) Acre State Plan for Deforestation and Forest Fires Prevention and Control (2010); 3) Acre State Plan for Water Resources (2012); and 4) Acre State Plan for Risk Management of Environmental Disasters (2012). The policy documents were coded and analyzed on their perspectives on and framing of adaptation to climate change.

Second, we conducted 18 semi-structured interviews with stakeholders in Acre's climate governance, including subnational government, local and international NGOs, indigenous organizations and university representatives. The objective of the interviews was to better understand what subnational climate governance in Acre entails, and how much it is focused on climate mitigation and adaptation. Also, through the interviews we tried to underpin the advantages and disadvantages of climate collaborations, as well as the different institutional perspectives on how to improve Acre's AG. We used a common interview protocol, with open interview questions. The questions were pre-formulated, and their sequence was fixed. The interviews were divided into four sections: 1) institutional questions; 2) climate governance; 3) climate justice; and 4) future climate governance. The interviews were conducted by both authors in the Portuguese language. Due to time and financial constraints, half of the interviews were conducted face-toface and the other half using Skype as a viable alternative for data collection (Iacono et al. 2016). The transcribed interviews were coded and qualitatively analyzed, using MaxQDA software for qualitative data analysis.

\section{Case study: Acre state}

Acre state, situated in the Southwestern Amazon and bordering Peru and Bolivia, shows a historical struggle for sustainability and environmental awareness; Chico Mendes, rubber tapper and environmentalist from Acre, died in 1988 in defense of the forest. After his death, his

\footnotetext{
4 The subnational states that form the Brazilian Amazon are: Acre, Amapá, Amazonas, Mato Grosso, Pará, Rondônia, Roraima, Tocantins and a part of Maranhão.
} 
dream of forests conservation combined with development, was realized with the creation of Extractive Reserves (RESEX): sustainable-use protected areas, considered social experiments for community-based forest management (Brown and Rosendo 2000). Mendes' death led to Acre's transition towards a sustainable development model in support of forest protection, known as 'Florestania' (literal translation: forest citizenship). The Florestania model, introduced by the 1998 State government, combines market-oriented strategies with local participation and social development and brought innovations in forest-based economy and environmental governance (Schminck et al. 2014). In 1999, a first step towards Florestania was the implementation of an Economic and Ecological Zoning Plan (ZEE), dividing Acre into territorial zones, depending on their land use activities and potentials. In 2007, based on ZEE, Acre implemented its Policy for Valuing Forest Environmental Assets (PVFEA), which comprises programs and projects that promote forest-dependent livelihoods by a certification system and payment for ecosystem services. In 2010, Acre consolidated its sustainable development model into a law that established the State System of Incentives for Environmental Services - SISA. SISA is considered the world's first and most advanced jurisdictional programs for the Reduction of Emissions from Deforestation and Degradation (REDD) (World Wide Fund for Nature 2013).

Acre is a member of various transnational networks. In 2008, it co-founded the Governor's Climate and Forest (GCF) taskforce: a platform for subnational governments to advance policy innovation and leadership. GCF promotes realistic pathways to forest-maintaining subnational development. In 2012, Acre was the first example of a REDD+ transaction under the Global REDD for Early Movers (REM) program, financed by the German Development Bank (KfW). REM is a program at the national or subnational level (jurisdictional programs) that supports REDD pioneers by results-based payments for reduced deforestation. A third network is the so-called MAP initiative: a trinational collaboration between Madre de Dios (Peru), Acre (Brazil), and Pando (Bolivia). Founded in 1999, MAP is based on the informal organization of the subnational governments and civil society of the three bordering countries that jointly discuss regional aspects of global environmental change (Perz 2016).

\section{Climate adaptation framing}

Acre's subnational policies show a focus on climate mitigation through deforestation reduction, rather than adaptation (see table 2). SISA's first implemented program is on carbon sequestration, and its main goal is to reduce emissions from deforestation and degradation. It follows the 2010 State Plan for Deforestation Prevention and Control (PPCD), whose main objective is to reduce deforestation and degradation of native vegetation, to control forest fires and to promote the maintenance of ecosystem services. Both SISA and PPCD do not mention any specific climate adaptation measures. 
Table 2. Acre's Climate Policies and Adaptation

\begin{tabular}{|c|c|c|c|}
\hline Subnational Policy & Objective & $\begin{array}{c}\text { Climate } \\
\text { adaptation }\end{array}$ & $\begin{array}{l}\text { Adaptation } \\
\text { Measures }\end{array}$ \\
\hline $\begin{array}{l}\text { System of Incentives for } \\
\text { Environmental Services } \\
(2010)\end{array}$ & $\begin{array}{l}\text { To promote the maintenance and } \\
\text { expansion of ecosystem services and } \\
\text { products }\end{array}$ & Not mentioned & $\begin{array}{l}\text { No specific climate } \\
\text { adaptation measures }\end{array}$ \\
\hline $\begin{array}{l}\text { Acre State Plan for } \\
\text { Deforestation and Forest } \\
\text { Fires Prevention and } \\
\text { Control (2010) }\end{array}$ & $\begin{array}{l}\text { To reduce deforestation and the } \\
\text { degradation of native vegetation, } \\
\text { as well as to control forest fires, } \\
\text { promoting the maintenance of } \\
\text { ecosystem services. }\end{array}$ & $\begin{array}{l}\text { One of the objectives } \\
\text { is contributing to } \\
\text { climate mitigation and } \\
\text { adaptation. }\end{array}$ & $\begin{array}{l}\text { No specific climate } \\
\text { adaptation measures }\end{array}$ \\
\hline $\begin{array}{l}\text { Acre State Plan for Water } \\
\text { Resources (2012) }\end{array}$ & $\begin{array}{l}\text { To promote harmonization between } \\
\text { the multiple and competitive uses } \\
\text { of water and its limited and random } \\
\text { temporal and spatial availability }\end{array}$ & $\begin{array}{l}\text { One of its four } \\
\text { guiding principles is } \\
\text { the development of } \\
\text { climate adaptation } \\
\text { measures }\end{array}$ & $\begin{array}{l}\text { Program } 9 \text { mentions } \\
\text { various actions, } \\
\text { amongst which the } \\
\text { creation of an early } \\
\text { warning system and } \\
\text { strengthening civil } \\
\text { defense }\end{array}$ \\
\hline $\begin{array}{l}\text { Acre State Plan for } \\
\text { Risk Management of } \\
\text { Environmental Disasters } \\
(2012)\end{array}$ & $\begin{array}{l}\text { a) Prevention of Environmental risks } \\
\text { b) Reduction of Environmental risks } \\
\text { c) Confronting environmental risks }\end{array}$ & $\begin{array}{l}\text { Constructing } \\
\text { a pathway that } \\
\text { combines risk } \\
\text { management, } \\
\text { climate adaptation } \\
\text { and sustainable } \\
\text { development }\end{array}$ & $\begin{array}{l}\text { Creation of a Situation } \\
\text { Unit to monitor and } \\
\text { control risks }\end{array}$ \\
\hline
\end{tabular}

Acre's State Plan for Water Resources (PLERH) addresses climate adaptation and mentions the development of adaptation measures as one of its guiding principles. PLERH proposes measures related to disaster risk reduction, such as the creation of an early warning system and strengthening of the state's civil defense. Finally, Acre's State Plan for Risk Management of Environmental Disasters stresses the importance of estimating the probability and impact of extreme climatic events and proposes the creation of a Situation Unit, to monitor and control these environmental risks.

The interviews confirm Acre's focus on climate mitigation, especially in relation to reducing its emissions from deforestation and forest degradation. IMC - Acre's Climate Change Institute - has two objectives: climate change mitigation and adaptation. However, it admits devoting approximately $70 \%$ of its time to mitigation and $30 \%$ to adaptation. The fact that IMC's main tasks are related to the implementation of SISA, explains its focus on climate mitigation. Next to its regulatory body IMC, the SISA-law also created the Company for the Development of Environmental Services (CDSA) and a State Committee for Validation \& Monitoring (CEVA). CDSA is a public-private company responsible to attract private investment for innovative mechanisms of low-emission development. CEVA, composed of government and civil society representatives, is responsible for the social monitoring of SISA and the revision and approval of its norms, regulations and 
sub-programs (World Wide Fund for Nature 2013). Like IMC, both CDSA and CEVA also support the implementation of SISA, which explains their focus on mitigation.

An important example of Acre's work on climate adaptation is the creation of the State's Environmental Risk Management Committee (CEGdRA) in 2008, with 42 member institutions. In order to prevent, prepare and provide rapid responses for environmental emergencies, it works in three technical chambers: a chamber on hazardous chemicals; a chamber on forest fires, severe droughts and deforestation; and a chamber on floods. In 2010, CEDdRA installed a "Situation Unit," where it monitors its water level, deforestation and forest degradation and provides alerts in case of droughts, floods or forest fires. The Situation Unit's aim is to assist in decision making and enable a rapid civil defense response.

\section{Advantages of climate collaboration}

In regard to climate collaboration, our data shows that all stakeholders work on both local and international levels, but hardly ever on the national level. MAP is mentioned as a successful example of AG. An advantage of this regional collaboration is the increased effectiveness of transboundary responses to extreme events. Also, it increases the chances for internationally financed projects; In 2013, collaboration in the MAP region led to a regional project on climate adaptation and river basins in the Amazon, executed by the Amazon Cooperation Treaty Organization (ACTO) and financed by the Global Environmental Fund (GEF) and the United Nations Environmental Program (UNEP). The project resulted in the implementation of a trinational early warning system for extreme climatic events.

Another mentioned advantage of collaboration is increased social inclusion and participation, leading to higher levels of trust. Acre's Florestania model provides room for intercultural stakeholder dialogue and keeps the collaborations moving. It also improved conflict management. The involved institutions relate well, they have common interests and fight for the same causes. In relation to overarching rules of cooperation, there are "rules of chivalry": collaboration and institutional relations depend very much on the personal relations of the actors, and as there are few institutions working on the issue of climate change, they always try to reach a consensus.

A third advantage is the available space for innovation. According to one of the interviewed stakeholders, "the local institutions are very important, and their actions are like seeds," stressing the local potential for climate innovation and experimentation. Acre's role as a pioneer in creating public-private partnerships for low-emission development has increased this space. Through its state company CDSA, it actively collaborates with the private sector, which, in comparison to the government, is more likely to take risks and use innovative approaches. When it comes to international collaborations, rules are generally dictated by the funders, and their flexibility depends on each partner's organization. Transnational collaborations, such as participation in the REM 
program that allowed a flexible use of the resource for local need, have led to a maximization and optimization of resources.

One last advantage is the bridges created through collaborations, mainly between the subnational and international levels. An example of such bridge is the collaboration between the local Acre Pro-Indigenous People Commission (CPI-Acre) and the international Governor's Climate and Forests task force (GCF), which were introduced to each other through Acre's membership of GCF. One positive aspect stemming from this collaboration is that it enables organizations to work on a specific theme, in this case indigenous peoples, without having the specific knowledge in-house. In general, local institutions can learn from their international partners about a different way of operating and exchange experiences and knowledge.

\section{Challenges of climate collaboration}

Challenges of climate collaboration are context-specific and are different for local, national and transnational collaboration. A challenge for local-national collaboration is the conflict of interest regarding deforestation policies. On the local level, Acre attempts to demonstrate that it is possible to develop without deforestation. However, national policies are contradictory and antagonistic towards low-emission development, and there is a lack of a macro-policy to low-emission development in the Amazon. Although transnational collaboration is considered easier, a mentioned challenge is for Acre to be 'visible' on the international level. It is still very difficult for the subnational level to unlock financial resources for climate and forest governance. Although the efficiency is much higher on the subnational level, most of the financial resources still go the national level.

As well as an advantage, Acre's pioneering role is also seen as a challenge. As SISA is unique and new to Brazil's climate governance landscape, there is no template to follow and Acre had to make an effort into institutionalizing and legalizing the issue of incentives for environmental services. Another challenge is that Acre often has no governability in regard to certain deforestation causes. For example, much of the deforestation in the Amazon is associated with roads or activities in neighboring states, such as the municipality of Boca do Acre in Amazonas state, where a lot of timber illegally leaves Acre. Borders, both on the subnational and national level, are a huge challenge and often lead to governance conflicts.

Climate communication is also mentioned as a challenge. Defining climate change and looking at it, not only from an environmental, but also economic and social perspective, is difficult when working together with diverse organizations. Also, informing civil society on the importance of the issue and the possible impacts of climate change is seen as a challenge. As a representative of an indigenous association put it: "our people do not understand the link between the international political debate on climate change and their daily lives. The concepts and terminologies used are 
often new and difficult to grasp." This could be seen in practice with the REM program: many REM beneficiaries did not clearly understand why they were receiving benefits.

Transparency on how the received international funding is spent and who is benefiting is a challenge for SISA. According to Acre's anti-REDD movement, the ones participating and profiting from REDD are the state's elite. They criticize REDD in general and Acre's SISA in specific and call it "false solutions incentivized by green capitalism," 5 as they are based on carbon emission compensation, instead of improving the state's sustainability. This relates to the lack of effective monitoring on SISA's impacts. Due to a lack of available data, it is impossible to assess whether current policies are effectively addressing the causes of deforestation and climate change, as was pointed out by representatives of different local NGOs. A last challenge is the fragility of Acre's climate governance system, which is very dependent on the subnational government. When the government changes, as was the case in 2019 on both the national and subnational level, this transition threatens the continuity of existing climate policies.

\section{Polycentric adaptation governance in the Amazon}

The first theoretical proposition of polycentric climate governance states that governance initiatives are likely to flourish at the local level. This is clearly visible in the state of Acre: its subnational climate governance model SISA is an example of Acre's pioneering role in climate governance. In 2010, long before the Brazilian government had elaborated its 2016 National REDD-Strategy, Acre launched its jurisdictional REDD-strategy. Although forest protection can also be seen as a form of indirect climate adaptation (Long 2013), Acre's SISA lacks a long-term vision and strategy on how to deal with the future consequences of climate change, as well as measures outside the forestry sector. An example of local level AG is the trinational MAP initiative, but since it is an informal initiative without any financial budget, the results are merely in the field of knowledge exchange and examples of best practices for regional disaster risk reduction.

The MAP initiative is also an example of the second proposition of polycentric theory: mutual adjustment. In the absence of a Brazilian adaptation plan, which was only finalized in 2016, and facing various extreme climatic events (Perz 2016), Acre started looking for alternatives to adapt to climate change. Through regional cooperation, it sought to increase its resilience to climate change in the MAP region. Mutual adjustment also led to bridges between the international and subnational levels, such as the transnational collaboration for forest-maintaining development under the GCF Taskforce and the German financed REM-program. However, both the GCF taskforce and the REM-program do not work on local climate adaptation to climate change. They hold a neoliberal perspective and see the forest as 'carbon credits.' This shows an often-overlooked limitation of polycentric systems: the element of power (Morrison et al. 2017). In the case of

\footnotetext{
5 Next to the information from interviewed stakeholders, this position and more information can also be found on the movement's website: https://chicomendes30.wordpress.com/
} 
Acre, we can see that although its institute for climate change is supposed to work on both climate mitigation and adaptation, in practice it works on what the international funds demand: reducing deforestation. A second limitation of polycentric systems in relation to mutual adjustment is its weaker legitimacy: it is not clear who is in charge of Amazon AG. Besides its thematic strategy on vulnerable populations, Brazil's NAP does not refer to the Amazon. On the subnational level, Acre's state policies on climate change do not mention any adaptation measures. Although Acre's water and risk management policy contain adaptation measures, they only refer to monitoring risks of extreme climatic events and do not propose a strategic approach to reduce vulnerability or strengthen regional resilience to climate change.

A polycentric approach encourages actors within domains to experiment with different approaches (Ostrom 2010). Acre can be seen as a laboratory for experimentation with many forms of low-emission and forest-based development with multi-level stakeholder participation (Schmink et al. 2014). An example is the active participation of indigenous populations and the incorporation of their perspectives in both the elaboration and implementation of SISA. The MAP initiative is also an example of experimentation and joint learning on regional adaptation actions by Acre's civil society. Polycentricity's fourth proposition points to increased levels of trust. Acre's longstanding governance model of Florestania and the fact that local organizations are used to working with each other, has increased the level of trust on the local level, in comparison to the national level. Local political leadership in implementing the Florestania model should not be overlooked. Florestania and its climate policies were all created during the twenty years (1998-2018) government by the Workers' Party (PT). In 2019, Acre's PT lost its governing position to the more conservative Progressive Party (PP), under the recently elected Governor Gladson Cameli. Cameli's election puts Acre's socio-environmental policies at risk and subjected to economic interests. During his first months as Acre's governor, Cameli has already tried to close down the IMC, but was not able to do so due to financial obligations with Germany and the UK under the REM program.

The last theoretical proposition highlights that local initiatives work best when there are overarching rules (Jordan et al. 2018). In the Amazonian context, we clearly see the need for overarching rules on adaptation. Although there are bottom-up initiatives on adaptation in Acre, such as the MAP initiative, there lacks a coherent and strategic approach to climate adaptation. Brazil's NAP hardly refers to the Amazon and does not provide any measures to increase the adaptive capacity of the Amazon region. This brings us to a first recommendation for improved AG: the elaboration of a regional adaptation plan for the Amazon focused on enhancing its adaptive capacity. We also recommend framing climate change not merely as an environmental risk, but as a barrier for regional development. The Amazon regional adaptation plan should therefore take social, cultural and economic risks into consideration. Building upon Acre's experience of incorporating indigenous knowledge in climate governance, we recommend basing adaptation actions on the interweaving of scientific and indigenous knowledge systems (Tengo et al. 2014). Instead of portraying the Amazon's indigenous populations as passive and vulnerable - as was 
the case in Brazil's NAP - they should have an active role in AG. We also recommend promoting a diversity of actors: actively involving the private sector, research centers and NGOs in the elaboration of climate adaptation actions does not only decrease dependency on the government, but also creates ownership. A last recommendation for improved AG is to strengthen transboundary collaboration in the Amazon. As the example of the trinational MAP initiative shows, crossing borders for collaboration leads to more effective solutions.

\section{Conclusion}

Both global and Brazilian AG are emerging, but due to its local application, there is the need to cross boundaries for collaboration. Global and national solutions to climate adaptation lack an adequate representation of local stakeholders with place-based solutions to adapt to climate change. Elinor Ostrom (2010) described the changing climate governance landscape as 'polycentric,' and invited scholars to use insights from polycentric theory to better understand its modes of operation. In this article, we applied theoretical propositions of polycentric climate governance to the Brazilian Amazon and discuss the implications of greater polycentricity for climate adaptation.

Adaptation in the Amazon is an example of double neglect: where adaptation is the often neglected component of climate governance (Biesbroek and Lesnikowski 2018), the Amazon region is neglected in Brazilian climate politics (Viola and Franchini 2018). On the one hand, polycentric climate governance has intensified this neglect, by transnational collaborations that are merely focused on reducing deforestation. On the other, bottom-up regional initiatives, like the trinational MAP initiative, show high potential for Amazon AG and the need to cross boundaries for effective adaptation. Besides crossing national boundaries, we need to cross boundaries between mitigation and adaptation. So far, the Amazon has been looked upon as an opportunity for global climate mitigation, but it is about time to include a focus on the socio-economic consequences of climate change.

\section{Acknowledgement}

We acknowledge the support received by the Portuguese Foundation for Science and Technology (FCT) for the doctoral scholarship SFRH/BD/129274/2017.

\section{References}

Adger, W. N., N. W. Arnell, and E. L. Tompkins. "Successful adaptation to climate change across scales." Global Environmental Change 15, no. 2 (2005): 77-86. doi: https://doi.org/10.1016/j.gloenvcha.2004.12.005 
Amundsen, H., F. Berglund, and H. Westskogh. "Overcoming barriers to climate change adaptation-a question of multilevel governance?" Environment and Planning C: Government and Policy 28, no. 2 (2010): 276-289. doi: https://doi.org/10.1068/c0941

Araos, M., L. Berrang-Ford, J. D. Ford, S. E. Austin, R. Biesbroek, and A. Lesnikowski. "Climate change adaptation planning in large cities: a systematic global assessment." Environmental Science and Policy 66, (2016): 375-382. doi: https://doi.org/10.1016/j.envsci.2016.06.009

Becker, B. K. “Geopolítica da Amazônia.” Estudos Avançados 19, no. 53 (2005): 71-86. doi: https://doi.org/10.1590/S0103-40142005000100005

Biermann, F., and I. Boas. "Preparing for a warmer world: towards a global governance system to protect climate refugees." Global Environmental Politics 10, no. 1 (2010): 60-88. doi: https://doi.org/10.1162/glep.2010.10.1.60

Biesbroek, G. R., C. J. A. M. Termeer, J. E. M. Klostermann, and P. Kabat. "Rethinking barriers to adaptation: mechanism-based explanation of impasses in the governance of an innovative adaptation measure." Global Environmental Change 26, (2014): 108-118. doi: https://doi.org/10.1016/j.gloenvcha.2014.04.004

Biesbroek, R., and A. Lesnikowski. "Adaptation the neglected dimension of polycentric climate governance." In Governing climate change: polycentricity in action?, edited by A. Jordan, D. Huitema, and H. Asselt, 303-19. Cambridge: Cambridge University, 2018.

Brazil. Intended nationally determined contribution: towards achieving the objective of the United Nations framework convention on climate change. Brasília, DF: Ministério das Relações Internacionais, 2015. http://www4.unfccc.int/Submissions/INDC/Published Documents/Brazil/1/BRAZIL iNDC english FINAL.pdf

Brazil. Plano nacional de adaptação à mudança do clima. Brasília, DF: Ministério do Meio Ambiente, 2016.

Brown, K., and S. Rosendo. "Environmentalists, rubber tappers and empowerment: the politics and economics of extractive reserves." Development and Change 31, no. 1 (2000): 201-227. doi: https://doi.org/10.1111/1467-7660.00152

Bulkeley, H., and M. Betsill. "Rethinking sustainable cities: multilevel governance and the 'urban' politics of climate change." Environmental Politics 14, no. 1 (2016): 42-63. doi: https://doi.org/10.1080/0964401042000310178

Bulkeley, H., J. A. Carmin, V. Castán Broto, G. A. S. Edwards, and S. Fuller. "Climate justice and global cities: mapping the emerging discourses." Global Environmental Change 23, no. 5 (2013): 914-925. doi: https://doi.org/10.1016/j.gloenvcha.2013.05.010

Hall, N., and A. Persson. "Global climate adaptation governance: why is it not legally binding?" European Journal of International Relations 24, no. 3 (2018): 540-566. doi: https://doi.org/10.1177/1354066117725157.

Hulme, M. Weathered: cultures of climate. London: Sage, 2017. 
Iacono, V. L., P. Symonds, and D. H. K. Brown. "Skype as a tool for qualitative research interviews." Sociological Research Online 21, no. 2 (2016): 1-15.

doi: https://doi.org/10.5153/sro.3952

Intergovernmental Panel on Climate Change - IPCC. Climate change 2013: synthesis report: contribution of working groups I, II and III to the fifth assessment report of the intergovernmental panel on climate change. Cambridge: Cambridge University, 2014.

Intergovernmental Panel on Climate Change - IPCC. "IPCC special report 1.5: summary for policymakers." In Global Warming of $1.5^{\circ} \mathrm{C}$. An IPCC special report on the impacts of global warming of $1.5^{\circ} \mathrm{C}$ above pre-industrial levels and related global greenhouse gas emission pathways, in the context of strengthening the global response to the threat of climate change, edited by V. Masson-Delmotte, P. Zhai, H. -O. Pörtner, D. Roberts, J. Skea, P.R. Shukla et al. Geneva: IPCC, 2018.

Jordan, A., D. Huitema, H. Asselt, and J. Forster. Governing climate change : polycentricity in action? Cambridge: Cambridge University, 2018. https://www.cambridge.org/ $\mathrm{pt} /$ academic/subjects/earth-and-environmental-science/environmental-policyeconomics-and-law/governing-climate-change-polycentricity-action?format $=H B \& i$ $\operatorname{sbn}=9781108418126$.

Jordan, A. J., D. Huitema, M. Hildén, H. Asselt, T. J. Rayner, J. J. Schoenefeld, J. Tosun, J. Forster, and E. L. Boasson. "Emergence of polycentric climate governance and its future prospects." Nature Climate Change 5, (2015): 977-982. https://doi.org/10.1038/nclimate2725

Lenton, T. M., H. Held, E. Kriegler, J. W. Hall, W. Lucht, S. Rahmstorf, and H. J. Schellnhuber. "Tipping elements in the earth's climate system." Proceedings of the National Academy of Sciences 105, no. 6 (2008): 1786-1793. https://doi.org/10.1073/pnas.0705414105

Lesnikowski, A., J. Ford, R. Biesbroek, L. Berrang-Ford, and S. J. Heymann.

"National-level progress on adaptation." Nature Climate Change 6, (2016): 261-264. doi: https://doi.org/10.1038/nclimate2863.

Long, A. "REDD+, adaptation, and sustainable forest management: toward effective polycentric global forest governance." Tropical Conservation Science 6, no 3 (2013): 384-408. doi: https://doi.org/10.1177/194008291300600306

Magnan, A. K., and T. Ribera. "Global Adaptation after Paris.” Science 352, no. 6291 (2016): 1280-1282. doi: https://doi.org/10.1126/science.aaf5002

Marengo, J. A., C. M. Souza, K. Thonicke, C. Burton, K. Halladay, R. A. Betts, L. M. Alves, and W. R. Soares. "Changes in climate and land use over the amazon region: current and future variability and trends." Frontiers in Earth Science 6, (2018): 1-21. doi: https://doi.org/10.3389/feart.2018.00228.

Ministério do Meio Ambiente. GT adaptação. Brasília, DF: MMA, 2013. http://www.mma.gov.br/política-sobre-mudança-do-clima/item/9143-gt-adaptação 
Morrison, T. H., W. N. Adger, K. Brown, M. C. Lemos, D. Huitema, and T. P. Hughes. "Mitigation and adaptation in polycentric systems: sources of power in the pursuit of collective goals." Wiley Interdisciplinary Reviews: Climate Change 8, no. 5 (2017). doi: https://doi.org/10.1002/wcc.479

Nepstad, D. C., C. M. Stickler, B. Soares- Filho, and F. Merry. "Interactions among Amazon land use, forests and climate: prospects for a near-term forest tipping point." Philosophical Transactions of the Royal Society of London: Series B, Biological Sciences 363, no. 1498 (2008): 1737-1746. doi: https://doi.org/10.1098/rstb.2007.0036

Okereke, C. "Climate justice and the international regime." Wiley Interdisciplinary Reviews: Climate Change 1, no. 3 (2010): 462-474. doi: https://doi.org/10.1002/wcc.52

Ostrom, E. "Polycentric systems for coping with collective action and global environmental change." Global Environmental Change 20, no. 4 (2010): 550-557. doi: https://doi.org/10.1016/j.gloenvcha.2010.07.004

Ostrom, V., C. M. Tiebout, and R. Warren. "The organization of government in metropolitan areas: a theoretical inquiry." The American Political Science Review 55, no. 4 (1961): 831-842. doi: https://doi.org/10.1126/science.151.3712.868

Pahl-Wostl, C., and C. Knieper. "The capacity of water governance to deal with the climate change adaptation challenge: using fuzzy set qualitative comparative analysis to distinguish between polycentric, fragmented and centralized regimes." Global Environmental Change 29, no. (2014): 139-154. doi: https://doi.org/10.1016/j.gloenvcha.2014.09.003

Perz, S. G. Crossing boundaries for collaboration: conservation and development projects in the Amazon. Lanham: Lexington, 2016.

Rayner, T., and A. Jordan. "The European Union: the polycentric climate policy leader?” Wiley Interdisciplinary Reviews: Climate Change 4, no. 2 (2013): 75-90. doi: https://doi.org/10.1002/wcc.205

Rosenau, J. N. "Governance, order and change in world politics." In Governance without government: order and change in world politics, edited by J. N. Rosenau, 1-29.

Cambridge: Cambridge University, 1992.

Schminck, M., A. Duchelle, J. Hoelle, F. Leite, and M. Vinício. "Forest citizenship in Acre , Brazil." In Forests under pressure : local responses to global issues, edited by P. Katila, G. Galloway, W. Jong, P. Pacheco, and G. Mery, 31-47. Vienna: International Union of Forest Research Organizations, 2014.

Steffen, W., A. Persson, L. Deutsch, J. Zalasiewicz, M. Williams, K. Richardson et al. "The anthropocene: from global change to planetary stewardship." Ambio 40, (2011): 739. doi: https://doi.org/10.1007/s13280-011-0185-x

Stickler, C. Fostering low-emission rural development from the ground up. San Francisco, CA: Sustainable Tropics Alliance, 2014. http://earthinnovation.org/wp-content/ uploads/2014/12/Fostering_Tropical_LED-R.pdf 
Stripple, J., and H. Bulkeley. Governing the climate: new approaches to rationality, power and politics. Cambridge: Cambridge University, 2011.

United Nations Framework Convention on Climate Change - UNFCCC. Cancun adaptation framework. Bonn: UNFCCC, 2010. https://unfccc.int/resource/docs/2010/cop16/ eng/07a01.pdf.

United Nations Framework Convention on Climate Change - UNFCCC. Paris agreement. Bonn: UNFCCC, 2015. https://unfccc.int/process-and-meetings/the-paris-agreement/ the-paris-agreement.

Viola, E., and M. Franchini. Brazil and climate change: beyond the Amazon. New York, NY: Routledge, 2018.

Vogel, B., and D. Henstra. "Studying local climate adaptation: a heuristic research framework for comparative policy analysis." Global Environmental Change 31, (2015): 110-20. https://doi.org/10.1016/j.gloenvcha.2015.01.001

World Wide Fund for Nature - WWF. "Environmental service incentives system in the State of Acre, Brazil: lessons for policies, programmes and strategies for jurisdictionwide REDD+." WWF, October 21, 2013. http://assets.wwf.org.uk/downloads/ sisa_report_english.pdf 